The Sabbatean Prophets 



\section{MATT GOLDISH}

\section{The Sabbatean Prophets}

HARVARD UNIVERSITY PRESS

Cambridge, Massachusetts, and London, England 2004 
Copyright $\odot 2004$ by the President and Fellows of Harvard College All rights reserved

Printed in the United States of America

Library of Congress Cataloging-in-Publication Data

Goldish, Matt.

The Sabbatean prophets / Matt Goldish.

p. $\mathrm{cm}$.

Includes index.

ISBN 0-674-01291-7 (alk. paper)

1. Sabbathaians-History-17th century. 2. Prophecy-History-17th century.

3. Shabbethai Tzevi, 1626-1676. 4. Messiah-Judaism-History of doctrines. I. Title.

BM199.S3G65 2004

$296.8^{\prime} 2-\mathrm{dc} 22 \quad 2003058694$ 
For Richard H. Popkin 
